International Journal of English Literature and Social Sciences
Vol-6, Issue-3; May-Jun, 2021
Journal Home Page Available: https://ijels.com/
Journal DOI: $10.22161 /$ ijels

\title{
Professional Music Practice: The Nigeria Example
}

\author{
Jayeola, Folorunso David
}

Department of Music, Alex-Ekwueme Federal University Ndufu-Alike Ikwo (FUNAI)

Received: 21 Feb 2021; Received in revised form: 29 Apr 2021; Accepted: 12 May 2021; Available online: 27 May 2021

(C)2021 The Author(s). Published by Infogain Publication. This is an open access article under the CC BY license

(https://creativecommons.org/licenses/by/4.0/).

\begin{abstract}
Nigeria is known to be a multi ethnic nation that practices different kinds of music. It has also been observed that not all Nigerian performers are actually professionals in their various areas of specialization because of the standard of their performances. Moreso, some claim to be music professionals because they are academic musicians. Practicing music professionally means to be skillful, versatile, creative, expressive, educative, inspiring, etc. Therefore, this research reviews who really are professionals in music practice and gives some important tips for a professional in music practice. It makes expositions in some areas of musical professionalism in Nigeria, such as; Professionalism in Vocal Music (Sacred and Secular), Professionalism in Instrumentation, Professionalism in Church Music, Professionalism in Pop Music, Professionalism in African Music and Professionalism in theory of Music. The researchers find this work necessary because it brought out what it takes to practice music professionally and expresses why an academic musician should also be more skillful in practice in other to prove the worth of using the word "Professional".
\end{abstract}

Keyword-Professionalism, Music, Musician, and Academic Musicians.

\section{INTRODUCTION}

It is good for everyone to know that it is essential for any one that wants to be successful to be a professional. For some, being professional might mean dressing smartly at work, or doing a good job. For others, being professional means having advanced degrees and many certificates framed and hung on the office wall.

In Nigeria some musicians are seen as academic musicians, while some are seen as performing musicians. Today, most Nigerians see only the performing musicians as the professional musician because these are the kind of musicians that give them what they need musically at a particular point in time. Explaining further on this Okafor (2005) noted that, disqualify a person being called a musician. Indeed, in the modern context, he lays total claim to being a musician. But, then, there are other people gifted excellent performers who may not be trained academically or formally in the art, but whose natural talents release music, which the society accepts. These are the master musicians. (p.1).

Professionals are opposed to the amateur. Therefore, both the academic music professionals and the performing music professionals should do what they know best in order to project their professionalism in their various specific areas.

Froehlich (2007) explains that "to be musically professional, means to be part of the community of people who earn livings making music". It means that a professional musician is duty bound to affect his 
community positively in almost every sphere of life of all the members of the community.

Fortune (2011),had also thrown some light towards the contributions of professional musicians in promoting the social, religious, and material life (thereby raising the standard of living) of Nigerians. She explained further when she said that,

This is glimpsed through participation in musical activities (by individual members of the society, and collectively as members of the society) as performers and as the audience. The contribution is observed in the sphere of health, economy, education, social control, symbolic representation, literature, communication, emotional expression, aesthetics, rejuvenation, maintenance and continuity of history and tradition, facilitation of religious and social events, and the creation of group identity and solidarity. All these foster developments. (p.28).

Without any argument, professionals are always prepared to produce work of high qualityand reputable standards. Professionalism in music therefore requires the following: Specialized knowledge, Competency, Honesty and Integrity,

Respec

t, Accountability, Self-regulation, Image. etc.

\section{What is a 'Profession'?}

Most scholars have successfully been able to give a definite understanding of what a 'profession is in their various perspective. According to the Oxford English Dictionary (2020) express that "a profession involves occupation (whether career or vocation), knowledge, application, training and formal qualification, with the last two regarded as normal but non-essential". In the same way, Merriam-Webster Dictionary (2014) define a profession as a"a calling or a vocation requiring specialized knowledge and often long and intensive academic preparation". The most accessible concept and definition is the dictionary, yet most scholars do not limit the understanding of what profession is solely on dictionary definition. According to Cruess, Johnston, and Cruess (2004), suggest the following definition:

"a profession is an occupation whose core element is work based upon the mastery of a complex body of knowledge and skills. And like Pound they invoke a sense of calling in which specialised knowledge is used in the service of others and whose members are governed by codes of ethics and profess a commitment to competence, integrity and morality, altruism, and the promotion of the public good within their domain" P.75

In a general view a profession is an occupation, vocation of an expertise, where the knowledge is usually utilized in helping or serve of other without the skills. Most profession have a code of conduct that guide their services, integrity and morality. Usually, professions are their members are accountable to the society of which they are needed. Examples of approved professions in Nigeria are: Law, Teaching, Business, accounting, etc.

The concept of Music, Musician and Academic Musician

There is obviously no music musician and no musician without music. Music being an act of singing to suit the soul of an individual or a group of people at a given time with an accompaniment of either dance of instrument, or in most cases the both. It's very important to note that what makes music to someone could be refers to noise to another because of individual choice. When music is no more pleasant to the hearer, it otherwise known as a noise. However, musicians are generally not only someone who sing. There are other areas which professionals' functions that qualified them as musician. Among those areas on which professionals can function to be refers to as a musician are;

- Composer musician

- Arranger musician

- Instrumentalist musician

- Theorist musician

- Academic musician

- Popular musician

- Traditional musician

Academic Musician: In Nigeria, most people do not see academics a musician as musicians are only those who do the singing only on the stage either in gospel or popular style. Academic musicians are those who have gone through the four walls of the classroom to formally study music and a course and certified. These set of personality are professionals and musicians in their various specialization areas. An academic who is a composer is technically a musician for he do the composition and while the performer do the singing. The same is applicable to other area of academic music specialization.

\section{Professionalization in Music}

Nigerian music is so elaborate that one cannot just summarize the specialization areas. There are various areas 
in which musicians professionalize in Nigeria. However, those areas discussed here are not specifically for the academic musicians or non- academic musicians, but rather general professionalism in music.

\section{Professionalism in Vocal Music}

Professionalism in Vocal Music rather refers to professional singers. Ekwueme (2008) pointed out that singing is the action of making musical sound with voice. Moreso, she explained that the technical and professional manipulation of these organs make singing a success. Vocal music in Nigeria is a one of the peculiar areas of specialization in Nigeria music industry. These are the types of music performed, and have texts, lyrics, or wordings that have to be sung to certain melodies or tunes. People under this category are known as Professional Singers. However, Professionals in this area can be grouped into two:

\section{i. Secular \\ ii. Sacred/ Ritual}

Secular Vocal Music - These are the singers that haveno restriction whatsoever. Thisareaseem to be free for all kind of music. Secular singers perform for pleasure and leisure on one hand and on the other they perform a collection of songs that take care of social and contemporary events that take place in the community from time to time.

Sacred Vocal Music - This kind of vocal music is otherwise known as religious music. By sacred/ritual, we mean those music that focus more on religious phenomenon of life. Professional singers of this category therefore intend to assist the consumers on matters relating to their spiritual being. They help to indoctrinate people on religious beliefs. Nigeria is a country knownfor the practice three main religious namely Christianity, Islam and Traditional religion. Each of these types have professional singers of their own.

They are classified as follows:

i. Professional Christian Vocal Music - these are Christian gospel music professional. Their music have Biblical lyrics, and are popularly known in Nigeria as Professional gospel musician.

ii. Professional Muslim Vocal Music professional under this category sing for the Muslim faith. Their song is more of Quran lyrics.

iii. Professional Ritual Vocal Music -Singers under this group are also called traditional professionals. An Ordinary singer cannot sing well for the worshippers under this faith because itinvolves some incantation that has to go along with their musical chanting, especially during initiations. Professionals in this category also perform annually duringfestivals, to appease deities such as Songo, Ogun, Egungun, Obatala, Bori, Arugugu, Atilogu, etc.

\section{Professionalism in Instrumentation}

In music, instrumentation is the particular combination of instruments employed in a composition, and to the properties of those instruments. In Western music, instrumentation is sometimes used as synonyms for orchestration.

In Nigeria, this is what we call instrumental music and itrequires collection of indigenous musical instruments playing different rhythmic pattern to make a meaningful whole.Here no word is involved i.e no singing takes place; it is all about playing of drums, rattles, $u d u$ (idiophones) etc. Efficiency or professionalism in Nigerian instrumental music can be observed during the performances of local music genres. Each instrument is given a role to play that is lead role or supportive role. Lead instrument is often called "mother instrument", playing a "mother role". However, it has been observed that good instrumentation is as a result of professional instrumentalist. Instrumentation in Nigeria is usually used for entertainment, religious and as accompaniment during performances.

So many Professional instrumentalists in Nigeria earn their living through performance. Some instrumentalist in Nigeria performs for any faith or group, be it Christian faith, Islamic faith, and even for a secular band.

\section{Professionalism in Church Music}

Church music is a Christian music that is written for performance in the Church, or any musical setting of Ecclesiastical Liturgy. It is also music set to words expressing propositions of a sacred nature, such as a hymn. Church music in Nigeria could be traditional or Western type which involves group or solo singing.

Today in Nigeria, church music is grouped into two (2):

\section{i. Classical Music \\ ii. Contemporary Church Music/ Pentecostal Music}

The professional that handles Church music is often called a "Music Director" / "Choir master" as the case may be. He or she is responsible for the music affairs in the church. His professionalism is proven by his efficiency/ performance on some musical instruments, voicing, and knowledge of orchestration, composition / arrangement, and general musicianship. 


\section{Professionalism in Pop Music (Popular Music)}

Popular music by coinage is an older usage that carries the straight- forward meaning of "appealing to a wide audience". It is non- classical, commercially promoted type of music; consisting almost entirely of songs whether delivered by solo or group of vocalists. Commenting further on this Ekwueme (2008) explain that;

Popular music is a word that has to do with people. It is something that is liked and enjoyed by a larger number of people, or something that is suited to the tastes, needs and knowledge of ordinary people.Popular music, therefore, fit this definition and just as the name signifies; it is music that is enjoyed and appreciated by many people. It is usually a social dance music for people and cut across age, sex, class, and ethnic barriers. (p.101)

Professional popular musiciansare widely known is the society and they perform for various social gatherings at any given time. They give the audience exactly the taste of the kind of music they are interested in.

In Nigeria, popular musician are well known and recognized in the society. They are also rated as richer than the academic musicians, because people see them as professionalswhose music appeals to the greater members of the society. Most of the popular musicians in Nigeria are "Celebrities".

Okafor (2005) also added that professional musicians are those who perform music as their total profession. They may not be formerly trained but are often gifted. Their music moves in the markets through gramophone recordings, video recordings, broadcast and public performances. These are the popular musicians who have organized themselves to what we known as "Professional or Performing Musician Association of Nigeria, PMAN.

Today in Nigeria, many see popular musicians as the professionals because of their performances andpartially see the academic musicians as professional teachers for the classrooms.

The other group, that is (PMAN) usually sing in languages or dialects understood be almost everyone. They often perform in Pidgin English followed by their indigenous language. Very few of them compose and sing in English and examples include Bongos Ikwue, OnyekaOnwenu, Oliver de Coque etc.

\section{Professionalism in African Ethnomusicology}

According to Jayeola, F.D., Akintunde, O.S. \&Ugwu, A.S. (2019), established that "most African heritage and national values seem to have lost their originality to modernization, especially in Nigeria. Not only in the field of music, but also in every other arts and humanities. Africans are blessed with varied typologies of music. Music has always being a life phenomenon and is experienced right from the cradle (birth) to the grave (death). It will be agreed that every aspect/ stage of human life has a particular music attached to it.African music has its root in Africa by Africans and for the African people.

Nigeria has many professionals in African music both in Academics and in the non -academic circles. We are also blessed with different genres of music in which many Nigerians professionalize. These include; Afro - Juju, Waka, Fuji, Apala, Ikworikwo (Native blues), etc.

Professionals in this field, through their music educate the society, inform them, preserve history of the society, discuss societal values, entertain, etc. As a matter of fact, various expression about life generally and especially on the physical and spiritual existence of individual are channeled through African music. Professionals in African music are of two groups, academics and non-academics. Some of them are listed here under:

1. Academics

$\begin{array}{ll}\text { i. } & \text { MosunmolaOmibiyiObidike } \\ \text { ii. } & \text { Dan Agu } \\ \text { iii. } & \text { Christian Onyeji } \\ \text { iv. } & \text { Lucy Ekwueme } \\ \text { v. } & \text { Chukwuemeka Mbanugo } \\ \text { vi. } & \text { Okechukwu Ndubuisi } \\ \text { vii. } & \text { Femi Adedeji etc. }\end{array}$

2. Non-academics

$\begin{array}{ll}\text { i. } & \text { Ebenezer Obey } \\ \text { ii. } & \text { OnyekaOnwenu } \\ \text { iii. } & \text { Victor Owaifor } \\ \text { iv. } & \text { Fela Anikulapo Kuti, } \\ \text { v. } & \text { Sunny Ade etc. }\end{array}$

As a matter of fact, anyone who studied music is a professional in music.

\section{Professionalism in Theory of Music}

Theory of music is at the center of the study of music and as a matter of fact it accounts for up to sixty percent of the literary studies/ courses offered in various institutions. A very high theoretical knowledge is indispensable for composition which actually is its sister or closest ally. A 
good knowledge of theory facilitates the other areas of study. Applied study is said to be the theoretical studies put into practice.

Professionals in this aspect are more of the academics. Nigeria has many professionals in this aspect which theirefforts have contributed bountifully to the national growth and development of music in Nigeria. Professionals in this field do more of composition because of their sufficient knowledge of theory needed in composition. Nigeria has been blessed with great numbers of professionals in this field whose work have contributed immensely in the advancement of musical knowledge in a developing country like ours.

\section{CONCLUSION}

Professionals are known for their specialized knowledge. They have made deep personal commitments to develop and improve their skills, and where appropriate, they have the degree and certificates that serve as the foundation of this knowledge. This research has also guided the misconception that academics are not musicians

Nevertheless, not all the professionals in the various fields of music have a stable core of knowledge (and the academic qualifications that go with it): Also, not all areas demand extensive knowledge to practice successfully; and not all professionals have top degrees in their field. What matters most is that these professionals must have worked seriously and thoughtfully and sustained their craft in their specialized fields. There is also the need to up-date his knowledge in order he may still be relevant in that field.

\section{REFERENCES}

[1] Cruess, S. R., Johnston, S., \&Cruess, R. L. (2004). "Profession": A working definition for medical educators. Teaching and Learning Medicine: An International Journal, 16(1), 7476.

[2] Ekwueme, L. U. (2008). A basic guide to music appreciation. Lagos: Apex Book Limited

[3] Froehlich, H. (2007). Institution belonging, pedagogy discourse and music teacher education: The paradox of routinization". Forthcoming action, criticism, and theory of music education.Music Teacher Education: Black Rose Press.

[4] Furtune, I. (2011). Channeling traditional music to sustainable development. Journal of the Association of Nigerian Musicology: 5. 23-36

[5] Jayeola, F. D., Akintunde, O. S., \&Ugwu, A. F. Archives, Documentation and Ethnomusicology in Nigeria. International Journal of English Literature and Social Sciences, 4(5), 1606-1610. https://doi.org/10.22161/IJELS.45.53
[6] Merriam-Webster Dictionary. (2014). Retrieved from http://www.merriam-webster.com/ dictionary/profession

[7] Okafor, R.C. (2005). Music in Nigerian society. Enugu: New Generation Books.

[8] Oxford English Dictionary. (2020). Retrieved from http://www.oed.com/view/Entry/152052; http://www.oed.com/view/Entry/69909 